\title{
INFO INFO YANG MENDEBARKAN: \\ Punden Berundak, Toba Purba, Banjir Besar, Wawasan Nusantara, Gunung Padang
}

PRIMADI TABRANI

\begin{abstract}
This article is not yet a real research; it is more as a deep reflection. But those deep reflections are worth to be researched thoroughly by experts from many fields of study integratingly. Thinking of people in land-continent with many countries as Europe is different then thinking of people in one country as Indonesia, a maritime-continent. In land-continents thinking, sea is to separte, in maritime-continent Indonesia with its islands, sea is to unite, wawasan Nusantara as old as prehistory. Each country in a land-continent are eager to differentiate and defend to other countries by ethnic, language, religion, ideology, while in Indonsia as a maritime-continent, we is one country, several parts are slightly different but we are "one": "Bhinneka Tunggal Ika". In land-continent countries, a city with walls fortification, a country with great walls fortification are usual. While it is not so in Maritime-continent Indonesia, as is Trowulan the capital of the great empire Majapahit. Our school books says that the population of Indonesia comes from Asia, 5000 BC and 2000 $\mathrm{BC}$, while it is known that the migration of homosapiens has reach West Nusantara about 60 $80.000 \mathrm{BC}$, and experienced the ancient Toba Mountain great explosion and the three great floods. The west theory said that Indonesia is a country between two continents and two aceans, where culture, etnic, nation, religion, etc, criss cross ofer it. So Indonesia 'has nothing'. No local genius. Nusantara people cruises the Pacific and Indian ocean before Christ, the Atlantic in the first century. What about "Atlantis" and "Eden in the East" situated in Sundaland, that alter the world culture, history \& development? Has all this a connection with the mistery of Gunung Padang?
\end{abstract}

Keywords: Land-continent thinking, Maritime-continent thinking, Wawasan Nusantara, Bhinneka Tunggal Ika, Gunung Padang.

\section{INFO MENDEBARKAN 1: Manusia Benua-Darat}

Banyak turis "Barat" yang mengunjungi berbagai pulau, daerah, suku, di Indonesia terpesona keunikan setiap lokasi. Celakanya dengan sikap "samasekali tidak bersalab", terpesonanya dilanjutkan dengan pertanyaan yang membuat kita kelabakan. "Satu dengan yang lain begitu unik, begitu berbeda, oleh sebab itu mengapa lokasilokasi unik ini tak boleh merdeka?" (isu RMS misalnya).

Cara berfikir seperti ini tidak penulis sebut cara berfikir "Barat", tapi cara berfikir manusia "Benua-Darat" (Afrika, Asia, Eropa). Di Eropa jumlah negara puluban, sedangkan kita Negara Kesatuan Republik Indonesia. 
Di fihak lain kita bingung mengapa penduduk asli Amerika (Indian) dan penduduk asli Australi (Aborigin) tak boleh merdeka, bahkan sebagian harus hidup di dalam ghetto-ghetto di negerinya sendiri?! Mengapa pula di berbagai wilayah di trio benua-darat tsb seakan "tiada hari tampa perang?".

Untuk membedakannya, cara berfikir kita tidak, penulis sebut cara "Timur", tapi cara berfikir manusia Benua-Maritim dengan kepulauannya: 75\% Lautan dan 25\% kepulauan.

\section{Manusia Benua-Darat}

Umumnya diakui bahwa manusia muncul di benua Afrika dan kemudian menyebar ke seluruh panca benua: Afrika, Eropa, Asia, Australi, Amerika. Perkembangannya, penyebarannya dan perubahannya sepanjang sejarah manusia melalui jalur-jalur yang berbeda ke berbagai lokasi dengan lingkungan alam yang berlainan menyebabkan suatu saat ketika mereka bertemu kembali, seakan lupa bahwa mereka merupakan anak cucu nenek moyang Afrika yang sama. Setiap kelompok etnik dengan bahasa, wilayah, kepecayaan yang berbeda, cenderung jadi "fundamentalis" yang siap berperang untuk mempertahankan hak hidupnya karena khawatir dilibas oleh kelompok etnik yang lain. Sejarah perkembangan kebudayaan di trio benua-darat Afrika-Eropa-Asia sejak prasejarah memang dihiasi dengan beberapa lembaran hitam peristiwa "meghilang"nya etnik/bangsa, baik karena diusir, dibantai, atau dilibas, baik di Afrika, Eropa, Timur Tengah, Asia. Salah satu puncaknya adalah pembantaian Yahudi oleh Nazi Jerman. Tiap etnik/bangsa harus selalu waspada dan belum merasa aman bila tetangganya belum ditaklukkan. Bila tak mampu, maka mereka membuat pertahanan. Istana benteng, kota bertembok benteng, batas negara bertembok benteng, merupakan hal yang biasa.

Sejak kerajaan Mesir Kuno, Mesopotamia, Caesar, Roma, Iskandar Agung, kota benteng Aleppo, tembok besar Cina, Napoleon, Hitler, Stalin, kesemuanya mengulang pola berfikir yang sama: agresip atau defensip.

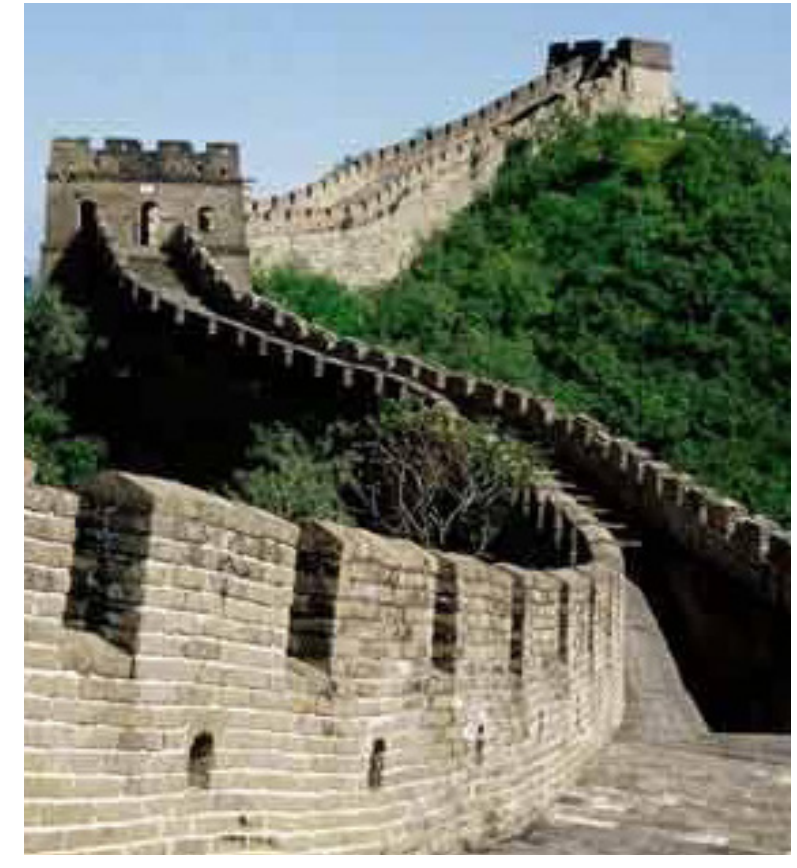

Gambar 1. Tembok Besar Cina

Dan saat ini masih berkecamuk "tiada hari tanpa perang", baik di kawasan terbelakang seperti perang etnik di Afrika, maupun di kawasan modern, seperti perang 'saudara' di: Irlandia, Yugoslavia, Siria, Irak, Yaman, Afganistan, Pakistan, perang segitiga Kroasia-Bosnia-Serbia, dan di Chehnya.

Memasuki abad XV ulah manusia benua-darat ini tetap dipraktekkan pada saat mereka "menemukan" benua baru Amerika dan Australi. Pembantaian bangsa Astec dan Maya, pelibasan suku-suku Indian Amerika, kelompok $\mathrm{Ku}$ Klux Khan yang rasialis di Amerika, pemusnahan suku Aborigin Tasmania. Penggiringan ke ghetto-ghetto bagi Indian Amerika dan Aborigin Australi. Untunglah abad ke XX tiba hingga bangsa yang "maju" itu malu bila tetap meneruskan tradisi berfikir manusia Benua-Darat.

Tentu saja ada beberapa pengecualian, suku/ bangsa(?) Gipsi, yang walaupun punya bahasa sendiri, tapi hidup sebagai pengembara, tanpa negara, tanpa lokasi. Karena itu perlu "damai" dengan Etnik/bangsa yang lain yang ditemuinya sepanjang pengembaraan mereka. 


\section{INFO MENDEBARKAN 2: Manusia Benua-Maritim \& Kepulaunnya}

Jaman Es Quartair sudah dimulai sekitar 110.000 SM. Sejumlah pakar, antara lain Mike Morwood, 2002:3 (Vision from the Past, Smithsonian Institution Press), menyebut bahwa sekitar $80.000-60.000$ tahun yang lalu, pengembaraan manusia benua-darat yang muncul di Afrika dan telah berkembang manjadi homosapiens tiba di tepi laut Asia Tenggara. Berbagai gelombang migrasi manusia yang telah memiliki tradisi "Benua-Darat" puluhan ribu tahun di belakangnya memasuki wilayah Nusantara. dan tertahan cukup lama (puluhan ribu tahun) di 'Nusantara Barat'. Ini karena dimasa itu ada 'Garis Huxley' dan 'Garis Weber' yang merupakan palung laut yang sangat dalam, hingga migrasi manusia masih lewat jalan darat, baik yang dari Asia maupun yang dari Taiwan dan Hainan. Mengarungi lautan ke pulau-pulau di samudera Pasifik belum terjadi karena teknologi menyeberangi laut belum berkembang. "Belajar" menyeberangi laut dangkal yang banyak pulaunya dan berdekatan, dengan garis pantai yang masih melebar di masa

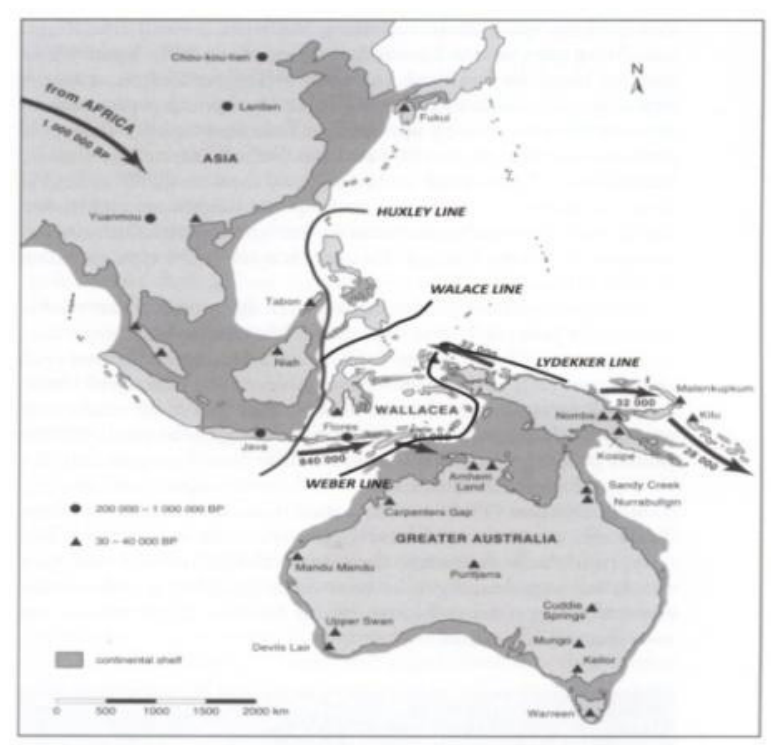

Gambar 2. Paparan Sunda dan Sahul

prasejarah, justru terjadi dari Jawa dan Kalimantan ke gugusan pulau di timurnya sampai Papua dan Australi. Mike Morwood dan George Chaloupka (1993, Jouney in Time, Reed Books of
Australia, Virginia, Australia) menyebut bahwa perantauan Nusantara tersebut telah mencapai Australi sekitar 60.000 SM. CHALOuPKa juga menyebut bahwa telah ditemukan garca (gambar cadas) prasejarah di Australi sejak sekitar 50.000 yang lalu (lebih tua dari garca prasejarah Eropa seperti Altamira, Dordogne, Lascaux,!!). Padahal seamula teori pakar Eropa menyebut bahwa garca prasejarah bermula di Afrika dan Eropa lalu menyebar dan akhinya sampai ke Australi.

\section{INFO MENDEBARKAN 3: \\ Katastrofi Purba: Ledakan dahsyat Toba Purba, Siklus Budaya}

Ketika jalur migrasi manusia dari Afrika yang sudah berkembang menjadi Homosapiens telah mencapai Asia Tenggara dan tertahan di Nusantara barat, gunung Toba Purba meletus. Letusan gunung api terdahsyat di dunia (sekitar 74.000 SM). Sejumlah pakar menyebut hal ini, antara lain Stephen Openheimer (1999, EDEN IN THE EAST, George Wiedenfield \& NichOLSON, Ltd, England). Bandingkan kedahsyatan Letusan Toba purba dengan Vesuvius, Tambora, Karakatau, dan sebagainya.

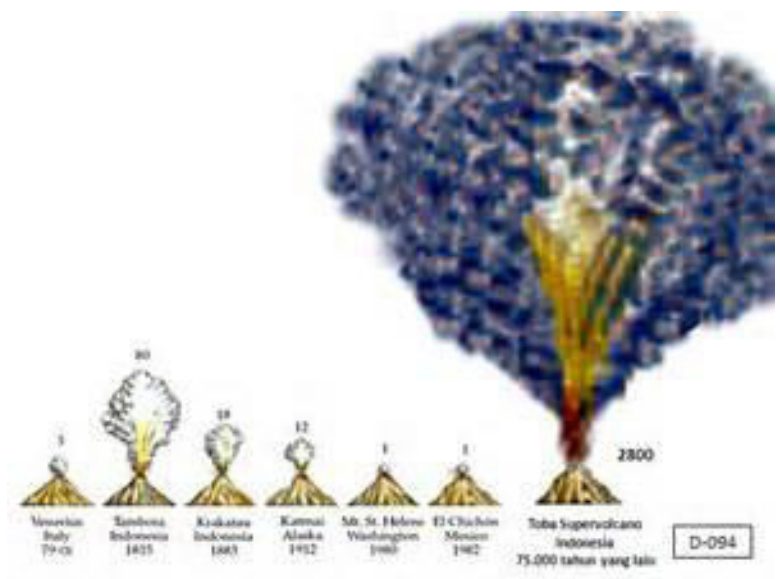

Gambar 3. Ledakan Toba Purba

Rangkaian letusan berlangsung selama 9-14 hari. Debu dan material vulkanis menembus atmosfer dan menyebar keseluruh dunia. Nyaris 10 tahun dunia dalam keadaan "remang-remang". Banyak species hewan dan tumbuhan yang punah. Jalur migrasi homosapiens terputus dan perkembangan homosapi- 
ens nyaris terhenti dan punah. Terjadilah siklus budaya, budaya seakan dipaksa mulai lagi dari 'awal'. Demikianlah migrasi homosapiens yang terputus dan telah tiba di Asia tenggara dan tertahan di Nusantara barat berhasil melaksanakankan migrasi "baru". Migrasi baru inilah yang kemudian menyebar keseluruh dunia.

\section{INFO MENDEBARKAN 4}

\section{Katastrofi Purba: Banjir banjir besar, Siklus Budaya}

Selain itu kini telah diketahui adanya tiga banjir besar yang melanda paparan Sunda \& Sahul, (termasuk Asia Tenggara), di akhir jaman es: sekitar 14.000, 11.000 dan 8.000 SM yang diakibatkan mencairnya es di kutub hingga permukaan laut naik. Ini disebut sejumlah pakar antaranya Stephen Openheimer. Banjir besar yang terakhir begitu dahsyat dan menenggelamkan semua dataran tinggi di paparan Sunda (warna kelabu pada peta) dan paparan Sahul. Sementara itu, perlahan muncullah kepulauan Nusantara. Proses ini memakan waktu lebih dari 60.000 tahun. Penghuni Nusantara berulang kali terpaksa mengungsi menghindari katastrofi-katastrofi tersebut.

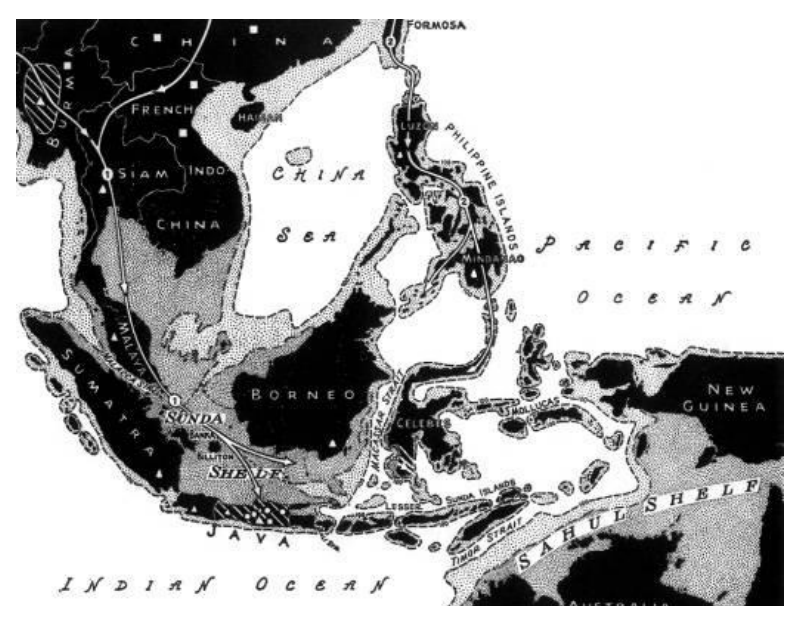

Gambar 4. Migrasi Baru

Kini telah diketahui rute darat pengungsian penghuni Nusantara Barat yang bukan hanya ke Asia, tapi sampai 'kembali' ke (back to) Afrika, lanjut ke Australia dan Tasmania, ke Eropa.
Dari gambar gambar tampak bahwa migrasi baru pasca Toba Purba meledak dan banjir banjir besar, ada yang dari Nusantara Barat menyusur pantai laut Cina Selatan ke arah Hainan dan Taiwan (bukan sebaliknya!) yang saat itu masih merupakan bagian dari paparan Sunda. Tentunya sebagian melalui laut ke Pasifik, ke Australia dan Tasmania. Perahu seperti apa yang mereka pakai?

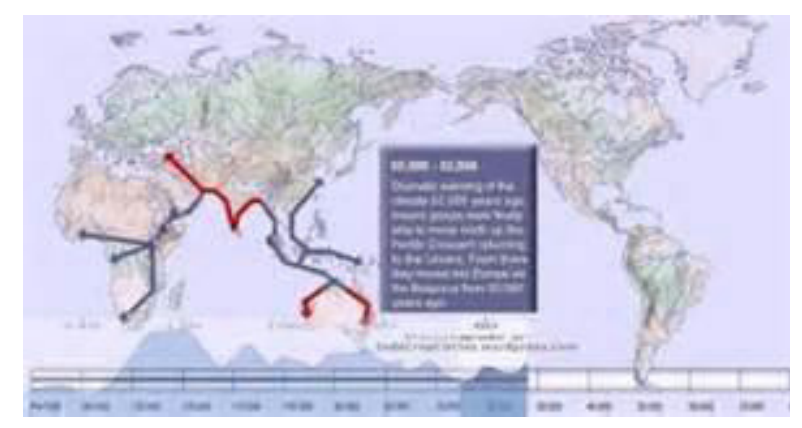

Gambar 5. Paparan Sunda

Kedua data mutakhir tsb dipicu oleh adanya pakar Benua-Darat (Barat) yang menafsirkan banjir besar dengan hilangnya "benua" Atlantis yang menurut mereka adalah Indonesia. Ada pula yang menyebut Asia Tenggara (termasuk Nusantara Barat) dimasa itu sebagai "Eden in the East" yang porak peranda karena ledakan dahsyat Toba Purba dan bencana banjir banjir besar. Kesemuanya berpendapat bahwa kebudayaan "Nusantara Barat" telah sangat tinggi, termasuk teknologinya. - kita bedol desa - membawa apa yang bisa dibawa saat mengungsi keluar pada peristiwa rangkaian banjir banjir dan gempa gempa kecil dan sedang. Sedang pada saat katastrofi dahsyat tentu tak mungkin. Yang pasti dalam bentuk 'budaya abstrak', yang ada dalam benak, pikiran, imajinasi nenek moyang kita, untuk dibudidayakan di tempat pengungsian kelak.

\section{INFO MENDEBARKAN 5:}

\section{Gunung Padang, Katastrofi Purba, Mitigasi Bencana.}

Ada 3 banjir besar (14.000, 11.000 dan 8.000 SM) disamping banjir sedang dan kecil diantara- 


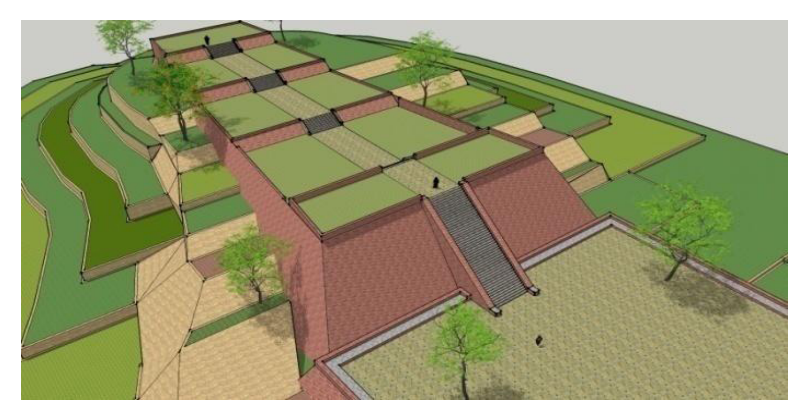

Gambar 6.

Rekonstruksi imajiner punden berundak Gunung Padang

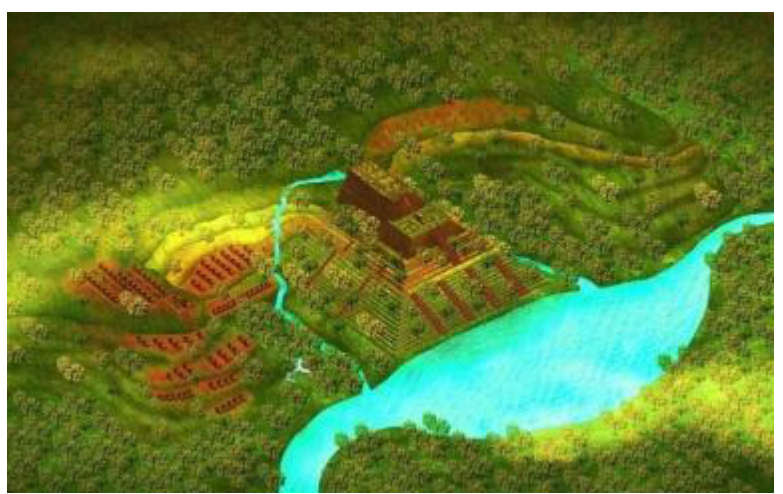

Gambar 7.

Rekonstruksi imajiner seluruh kompleks Punden berundak Gunung Padang

nya, dan sesudahnya. Banjir terdahsyat yang menenggelamkan semua dataran tinggi dan memporak perandakan permukaannya di Nusantara Purba terjadi di tahun 8.000 SM. Apa yang terjadi di banjir banjir sebelum 8000 SM, apakah nenek moyang kita belajar dari berbagai katastrofi tsb dan mengembangkan mitigasi bencana?

Dalam hubungan ini misteri Gunung Padang jadi menarik. Skala tarichnya 'berdekatan' dengan tarich katastrofi purba tsb. Diduga punden berundak Gunung Padang di Jawa Barat mulai dibangun sekitar 24.000 SM dengan perioda peralihan 15.000 SM, 10.500 SM dan $9.500 \mathrm{SM}$, terdiri dari empat tingkat dan tingkat terakhir (dipermukaan) sampai pada bentuknya yang sekarang. Bagian permukaan ini porak peranda karena katasfrofi purba. Namun tiga tingkat dibawahnya konstruksinya tetap terjaga, walaupun Gunung Padang berada dalam wilayah sesar Lembang dan sesar Cimandiri dengan banyak gangguan gempanya!! Ini menunjukkan bahwa mengalami sejumlah gempa dan sejumlah banjir, diantaranya dua banjir besar sebelum banjir besar terakhir (8000 SM) menyebabkan penduduk Nusantara mampu mengembangkan konstruksi teknologi bangunan tahan katastrofi dan mengembangkan mitigasi bencana!! Ketiga tingkat itu diduga dibangun oleh 'budaya' yang berbeda dan berjarak puluhan ribu tahun. Luas kompleks diduga sekitar 75 hektar (10 kali luas Borobudur) Baik teori "Atlantis" mapun "Eden in the East" menilai bahwa budaya Nusantara Barat pada saat banjir banjir besar sudah sangat tinggi dibanding budaya di bagian dunia yang lain yang berdasar teori lama masih berada di jaman Megalitikum yang 'primitip'. Oleh sebab itu muncul teori baru bahwa perkembangan kebudayaan tak selalu 'linier'. Bahwa suatu budaya yang sudah maju, bisa 'musnah' akibat katastrofi dahsyat purba, dan terjadilah sikulus kebudayaan, perkembangan budaya di wilayah tsb seakan harus mulai dari permulaan lagi.

Punden berundak Banten, dari jaman prasejarah (sesudah katastrofi katastrofi purba) seakan membenarkan hal itu. Kebudayaan seakan kembali dari awal mula. Punden berundak Candi Borobudur dari tahun $800 \mathrm{M}$ dan punden berundak Candi Sukuh dari tahun 1437 M pun kalah hebat dengan kehebatan punden berundak Gunung Padang (diduga antara 24.000 $-9.500 \mathrm{SM})$.

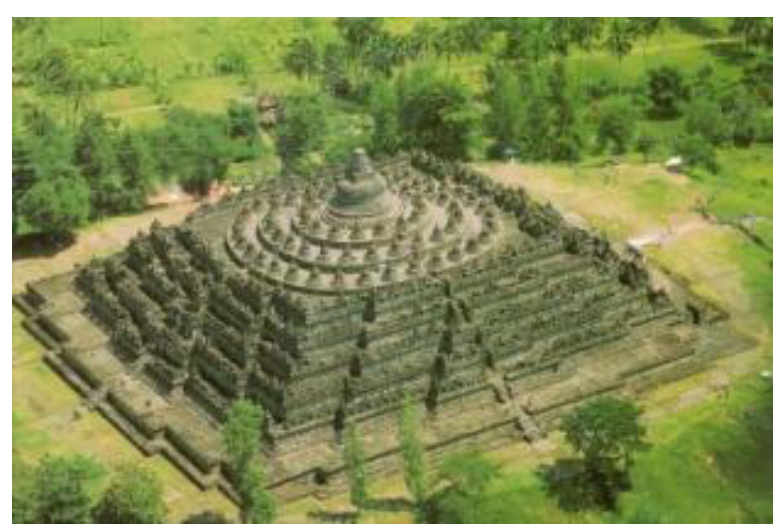

Gambar 8.

Punden Berundak candi Borobudur. 


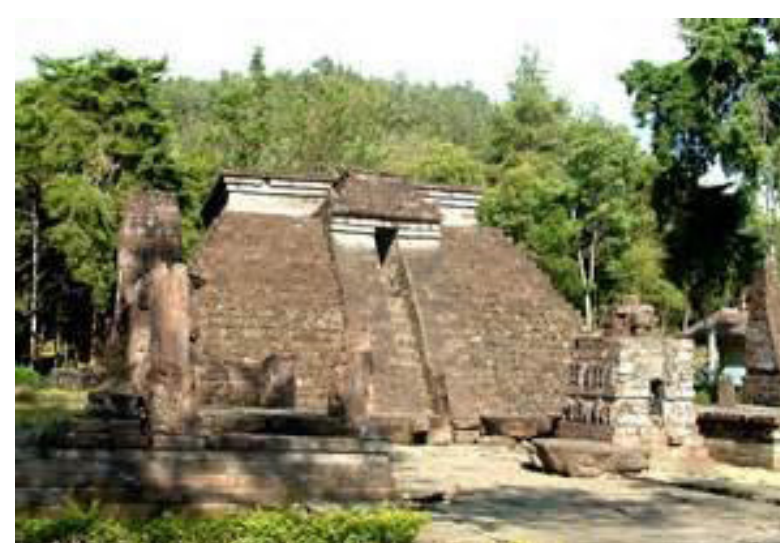

Gambar 9.

Punden Berundak candi Sukuh.

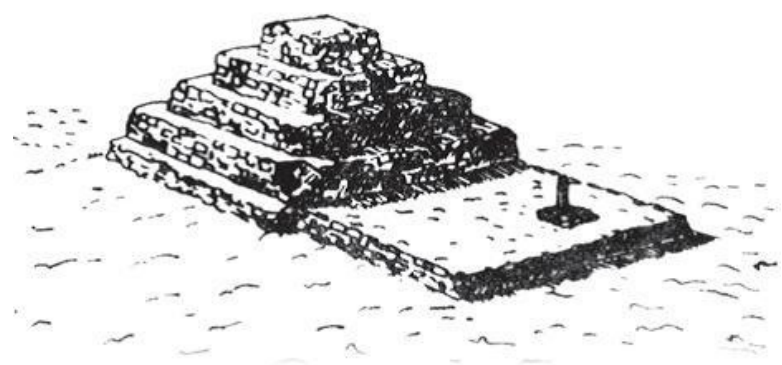

Gambar 10.

Punden Berundak Prasejarah di Banten

Bagaimana dengan banjir besar terdahsyat tahun 8000 SM yang menenggelamkan seluruh dataran tinggi di Nusantara Purba dan memporak perandakan pemukaannya? Tentunya tak ada pilihan lain selain mengungsi . Karena banjir besar terakhir meliputi seluruh Sunda land dan Nusantara Purba, tak ada pilihan lain ngungsi jauh jauh - terjadi 'migrasi migrasi baru lagi'.

Kini mulai tampak 'benang merah' punden berundak prasejarah Nusantara dengan Piramida Mesir (sekitar $2500 \mathrm{SM}$ ) yang merupakan pengembangan punden berundak. Begitu pun punden berundak - Ziggurat (sekitar 2000 SM) Mesopotamia, serta punden berundak di Mexico Amerika Selatan (berkembang diantara $3 \mathrm{SM}-\operatorname{abad} 9 \mathrm{M})$.

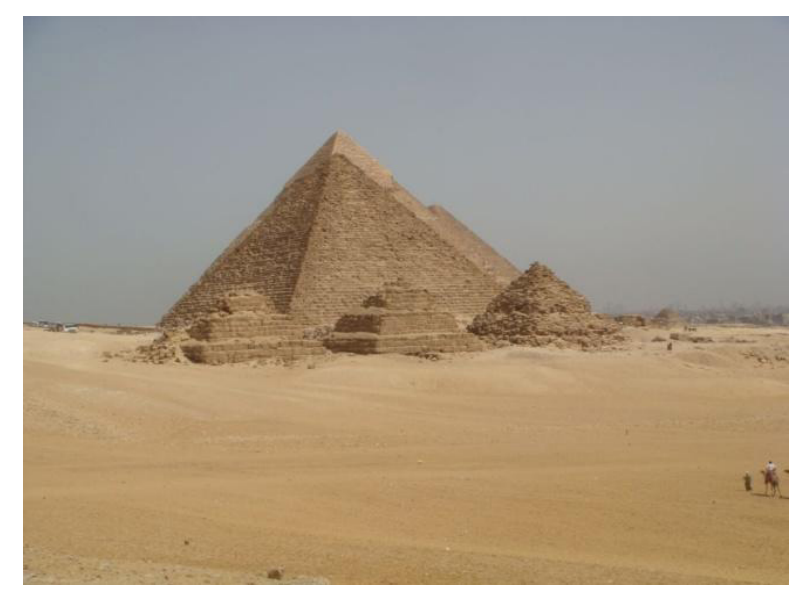

Gambar 11.

Punden Berundak - Piramid Mesir.

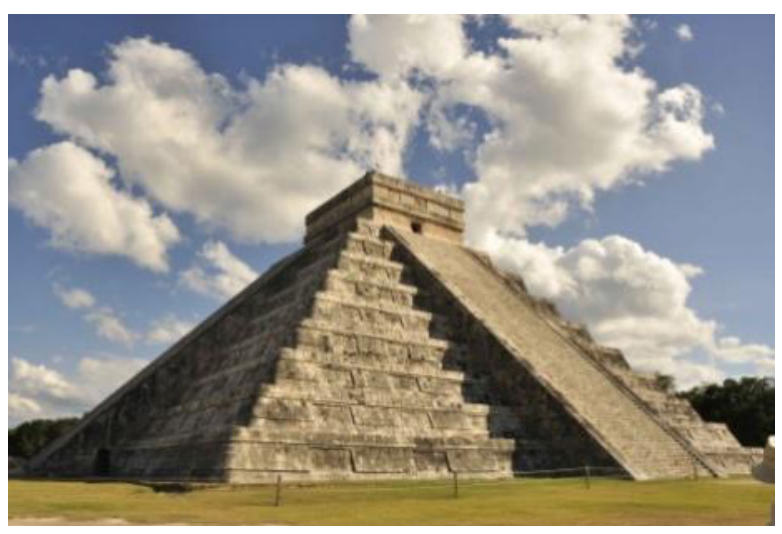

Gambar 12.

Punden Berundak Mesopotamia

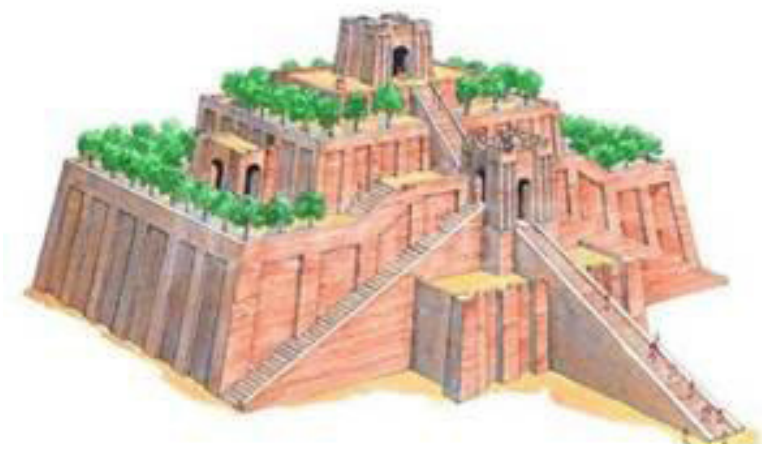

Gambar 13.

Punden Berundak Aztec di Mexico

Mungkinkah kesemua punden berundak di 'luar Nusantara' bermula dan merupakan penyebaran serta perkembangan budaya Nusantra Purba dengan tradisi 'bedol desa'nya, saat mengungsi dari bencana bencana dan katastrofi katastrofi purba tsb? 


\section{INFO MENDEBARKAN 6: Sejarah Kebudayaan yang 'keliru'}

Sementara itu yang di" ajar"kan para pakar benua-darat (barat) adalah bahwa cikal bakal manusia di Nusantara merupakan mereka yang masuk dari Asia 5000 SM (Proto Melayu) dan 2000 SM (Deutro Melayu). Semua buku sejarah kebudayaan di sekolah-sekolah kita juga menyebut seperti itu. Padahal telah disebut dipermulaan tulisan ini bahwa manusia Afrika yang telah berkembang jadi homosapiens telah mencapai Nusantara Barat antara 80.000 SM dan 60.000 SM, dan sempat mengalami katastrofi purba berupa letusan maha dahsyat gunung Toba Purba.

Di jaman es Quartair yang merupakan jaman es terakhir, naik turunnya permukaan laut pada Paparan Sunda dan Sahul, menyebabkan berkali kali garis pantai berubah maju mundur.

Merasa senasib sepenanggungan karena digembleng oleh Jaman Es Quartair ke arah terbentuknya kepulauan Nusantara, yang memakan waktu puluhan ribu tahun, para imigran tsb melebur jadi indo-Indonesia. Manusia pendatang bertradisi benua-darat itu ditransfer oleh lingkungan Nusantara menjadi manusia kepulauan di Benua-Maritim (sejak semula mencakup Sumatera sampai Papua). Peristiwa bertransformasinya bagian benua (paparan Sunda dan Sahul) jadi benua-maritim dan kepulauannya adalah peristiwa langka dan satu-satunya di bumi ini!

\section{INFO MENDEBARKAN 7: Wawasan Nusantara Setua Prasejarah}

Benua-Maritim, Kepulauan dengan laut sebagai pemersatu telah begitu menyatu dengan penduduk Nusantara, mereka satu-satunya penduduk bumi yang menyebut negerinya tidak dengan country/fatherland/motherland, tapi tanah air. Jadi 'wawasan Nusantara' sudah setua prasejarah. Tanah-air-laut-perahu, gambar perahu sudah diabadikan di garca prasejarah Indonesia, seperti di Sulawesi, Kalimantan, Timor, Arguni, Papua. Tidak hanya sampan untuk menyusuri sungai atau pantai, tapi pula perahu layar antar pulau. Misalnya di pulau Muna di Sulawesi Tenggara, pulau Kei Kecil (lihat gambar), di Maluku Tenggara, dan di Kalimantan Timur.

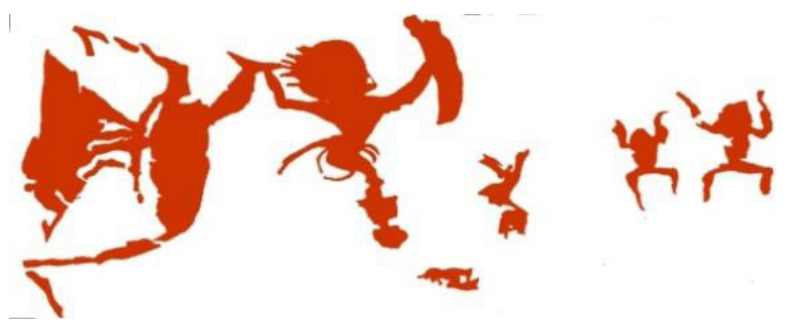

Gambar 14. Garca P. Kei Kecil

Jadi berbeda dengan gambar gua (garca) prasejarah di Eropa (Altamira, Dordogne, Lascoux, dan sebagainya) yang langka perahu layar.

Perahu cadik khas Nusantara yang sejak dulu ada dari Sabang sampai Merauke, dari P. Miangas sampai P. Rote, juga tersebar di seluruh kawasan Austronesia. Masalah ini juga diklaim para pakar teori benua-darat (barat) yang menyebut bahwa perahu cadik merupakan 'milik' penduduk pulau-pulau di Pasifik, padahal berdasar sejarah, dan perkembangan lingkungan yang telah diuraikan sebelum ini, 'pantasnya', cadik lahir di Nusantara, kemudian menyebar ke Austronesia. Di Western Australian Maritime Museum tersimpan koleksi perahu (outrigger canoe) cadik ganda memakai layar berasal dari pulau Lombok. Usianya 50.000 tahun!? Memang, walaupun langka, ada pakar Maritim benua-darat (barat) yang menyebut bahwa teknologi perahu cadik lahir dan dikembangkan oleh penduduk Nusantara yang bertanggung jawab atas penyebarannya ke Afrika Timur dan Oceania.

Pelayaran antara Madagaskar dan Asia Tenggara sudah mulai ramai sejak abad pertama Masehi (mungkin sebelum abad pertama Masehi), sejumlah pakar menyebut bahwa pelaut-pelaut Nusantara memegang peranan yang besar.

Antara lain Van Der Meulen, SJ., 1988, Indonesia Diambang Sejarah, Penerbit Kanisius, Yogya dan Soedjoko 1981, Ancient Indonesian Technology, Shipbuilding and Arms production around the XVI century, dalam Aspects of Indonesian Archeology, Pusat Penelitian Arkeologi Nasional,Jakarta. 


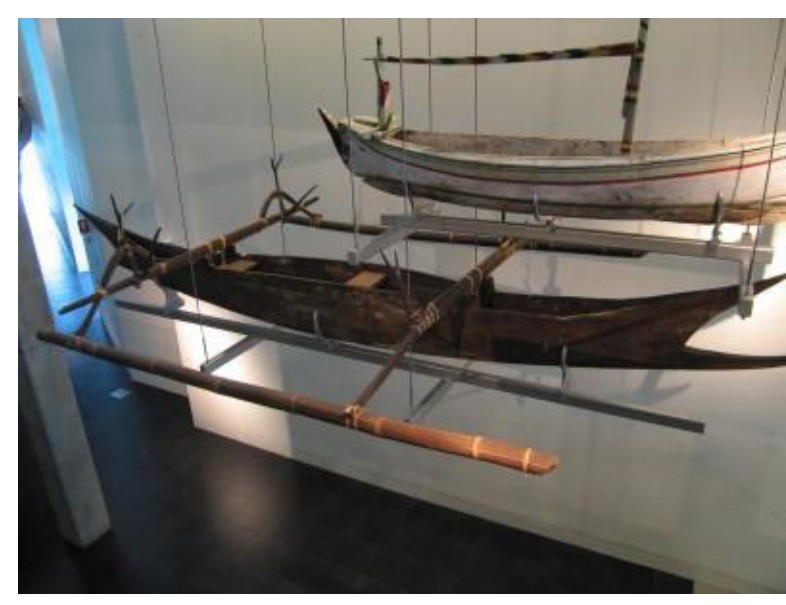

Gambar 15. Cadik Prasejarah

\section{INFO MENDEBARKAN 8:}

\section{Mengkerdilkan Manusia Nusantara}

Para penjajah, sesuai teori teori benua-darat (barat), menyebut Nusantara sebagai kepulauan diantara dua benua, dua samudera, tempat perlintasan bangsa-bangsa, ajaran, agama, ilmu dsbnya. Ini dilanjutkan dengan menyebut manusia Nusantara 'tak punya apa-apa'. Apapun 'kepandaian' yang kita miliki asalnya dari 'luar'. Wayang dari India, perunggu dari Dongson, perahu dari Hunan, dsbnya. Pokoknya tidak ada kejeniusan lokal. Para pakar prasejarah Indonesia, masalah ini perlu diluruskan!!

\section{INFO MENDEBARKAN 9:}

\section{Perantauan Nusantara}

Masih ada teori manusia benua-darat yang masih diakui sampai hari ini. Karena Nusantara di "cap" tak punya kepandaian apa apa, maka teori benua-darat mengklaim bahwa penyebaran manusia Asia ke Pasifik adalah bangsa Mongol dari Cina, begitu pula 'penemuan' Madagaskar . Memang dari segi ciri-ciri fisik ada kemungkinannya. Padahal telah disebut bahwa migrasi homosapiens telah mencapai Nusantara barat sekitar 80.000 - 60.000 SM. Dan mereka tertahan di Nusantara Barat, puluhan ribu tahun lamanya. Sejak migrasi manusia tiba di Asia Tenggara, meletusnya gunung Toba Purba (74.000 SM), jaman es Quartair yang dimulai sekitar 110,000
SM, sampai banjir besar pertama (14.000 SM), dan banjir besar kedua (11.000 SM) garis pantai Sundaland masih mirip. Baru setelah banjir besar terakhir, (8.000 SM), maka semua dataran tinggi di paparan Sunda dan Sahul tenggelam. Proses terbentuknya Nusantara baru selesai sekitar 5.000 SM. Jadi manusia dari Afika itu, dimasa prasejarah masuk ke Nusantara Barat, tertahan lebih dari 60.000 tahun di Nusantara Barat, berkembanglah bahasa Nusantara Barat. Setelah ledakan Toba Purba dan banjir-banjir besar, lahirlah migrasi baru, antara lain menyusur pantai Asia ke arah Hainan dan Taiwan (bukan sebaliknya!) yang saat itu masih merupakan bagian dari paparan Sunda (lihat gambar).

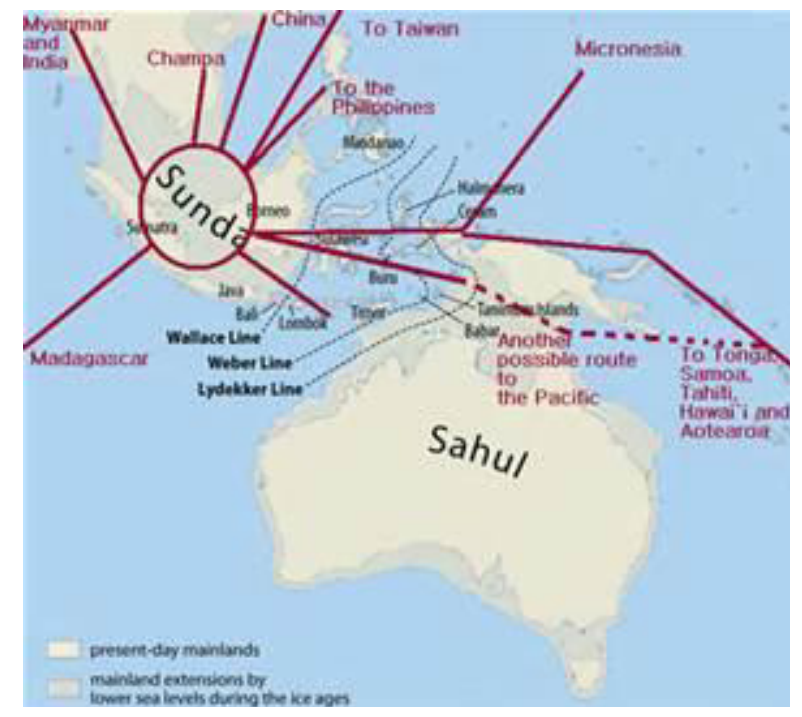

Gambar 16. Sundaland

Dimasa itu ada palung laut yang dalam antara Asia dengan Filipina, Kalimantan dengan Sulawesi dan antara Filipina dengan Sulawesi. Ini menghambat penyebaran ke samudera Pasifik, sebab belum dimiliki alat penyeberangan yang memadai. Belajar" menyeberangi laut dangkal yang banyak pulaunya dan berdekatan, dengan garis pantai yang masih melebar di masa prasejarah, justru terjadi dari Jawa dan Kalimantan ke gugusan pulau di timurnya smpai Papua dan Australi. Kemudian dengan mengembangkan teknologi maritim yang makin lama makin canggih, jauh lebih canggih dari Eropa pada masa yang sama, jejak jejak budaya penduduk 
kawasan Nusantara ini menyebar ke seluruh kawasan Austronesia: samudera Pasifik / Hindia. Oleh sebab itu yang lebih besar pengaruhnya pada rumpun bahasa Di Austronesia adalah Bahasa Nusantara Barat dibanding dengan bahasa Cina, Burma atau Indo-Arya. Kemungkinan berbagai bangsa yang masuk ke Sundaland berasal dari Cina, Burma, Indo Arya, dsb, melebur jadi Nusantara Barat dan baru menyebar ke Austronesia. Ini bisa menjelaskan adanya ciri-ciri fisik Mongol, Burma, Indo Arya, dsb, di Pasifik.

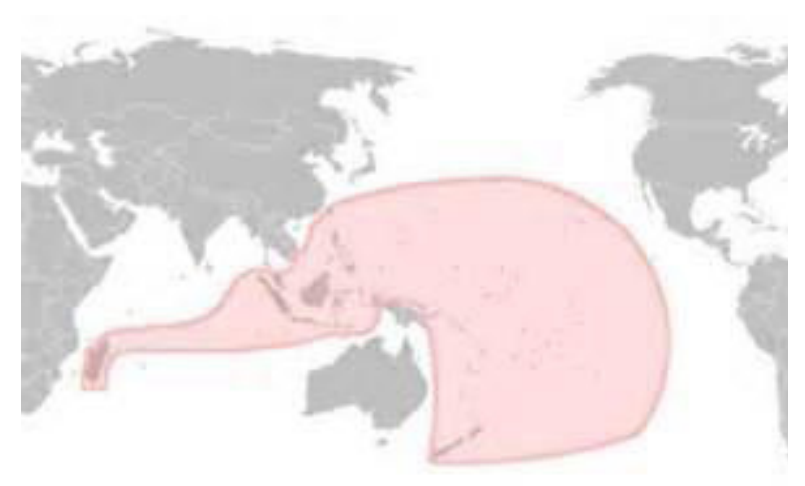

Gambar 17. Rumpun Bahasa Austronesia

Jejak jejak budaya penduduk kawasan Nusantara ini menyebar ke seluruh kawasan Austronesia, sejak Australi (Aborigin) di Selatan (60.000 SM), Madagaskar di barat sejauh 6500 $\mathrm{km}$, kepulauan Paskah di timur, Hawai di utara, Amerika Selatan di selatan, dan Selandia Baru di tenggara. Pelaut pedagang Nusantara sebelum permulaan Masehi telah mengarungi samudera Pasifik dan Hindia, dan di abad pertama menjelajah ke samudera Atlantik. Kita dinilai ahli dan banyak dipekerjakan di kapal bangsa lain. Kapal Nusantaralah yang terbanyak menjelajah Austronesia. Kita dianggap akhli teknologi perkapalan dan perdagangan. Kita telah mencapai Madagaskar dan kemudian Acra ditepi samudera Atlantik dipantai barat Afrika.

Di pantai timur Afrika berhadapan dengan Madagaskar muncul 'suku' Afro-Indonesia. (baca Robert Dick Read, 2008, Penjelajah Bahari, Pengaruh Peradaban Nusantara di Afri- ka, Penerbit Mizan, Bandung). Ada tenun Asia Tenggara yang muncul di Amerika Selatan dan jagung dibawa oleh pelaut pedagang Nusantara dari Amerika Selatan menyeberangi Samudera Pasifik ke Asia Tenggara, kemudian jagung menyebar ke India, Laut Tengah, Eropa dan Afrika, sebelum era Columbus. Semula diduga jagung dibawa Columbus dari Amerika Selatan ke Eropa!!.

\section{INFO MENDEBAKAN 10: Nusantara mengarungi semua samudera}

Sebelum Masehi manusia Nusantara telah mencapai Madagaskar. Perantauan Nusantara datang dalam beberapa gelombang dan berhasil mendirikan kerajaan Merina. Perdagangan Sriwijaya (sekitar pertengahan abad pertama) telah menjangkau Madagaskar. Sekitar 800 Masehi pedagang pelaut Nusantara telah membuka Rute Kayu Manis (asalnya dari Maluku) sampai ke kota Acra di pantai barat Afrika. Kayu manis yang ada di Acra itu dibawa oleh pedagang pelaut Nusantara melalui samudera Hindia dan Atlantik, lewat Tanjung Harapan di ujung selatan Afrika yang terkenal ganas ombak lautnya, lalu memasuki samudera Atlantik. Diduga kuat para pelaut pedagang Sriwijaya dengan perahu cadik Samudera yang sudah tertera pada relief candi Borobudur (800 M). Untuk diketahui Perahu samudera Pinisi baru muncul sekitar abad XIV Masehi. Dimasa itu baru Nusantara yang berani dan mampu mengarungi semua samudera didunia: samudera Pasifik, samudera Hindia dan samudera, Atlantik!!

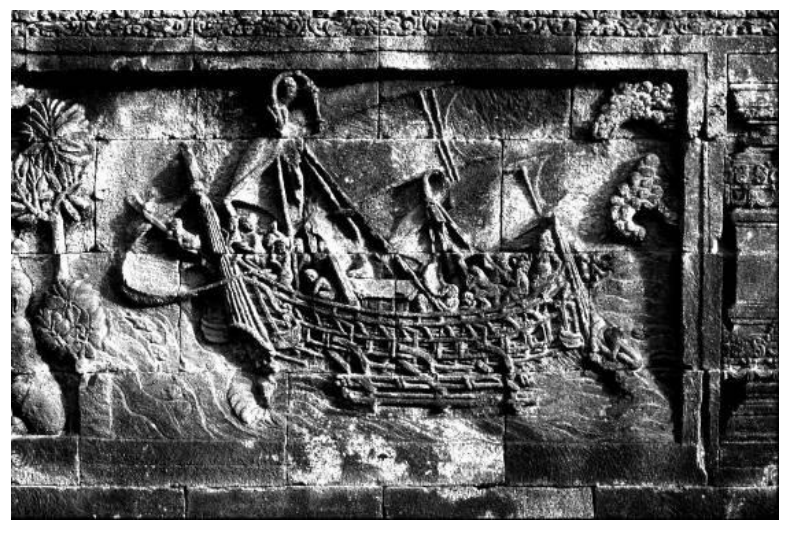

Gambar 18. Cadik Samudra Borobudur 
Untuk membuktikan hal itu, pada tahun 2003 dilaksanakan ekspedisi replika perahu cadik samudera Borobudur, menapak tilasi rute kayu manis abad ke IX tsb. Berangkat dari Jakarta (15.8.2003) ke Acra melalui Tanjung Harapan

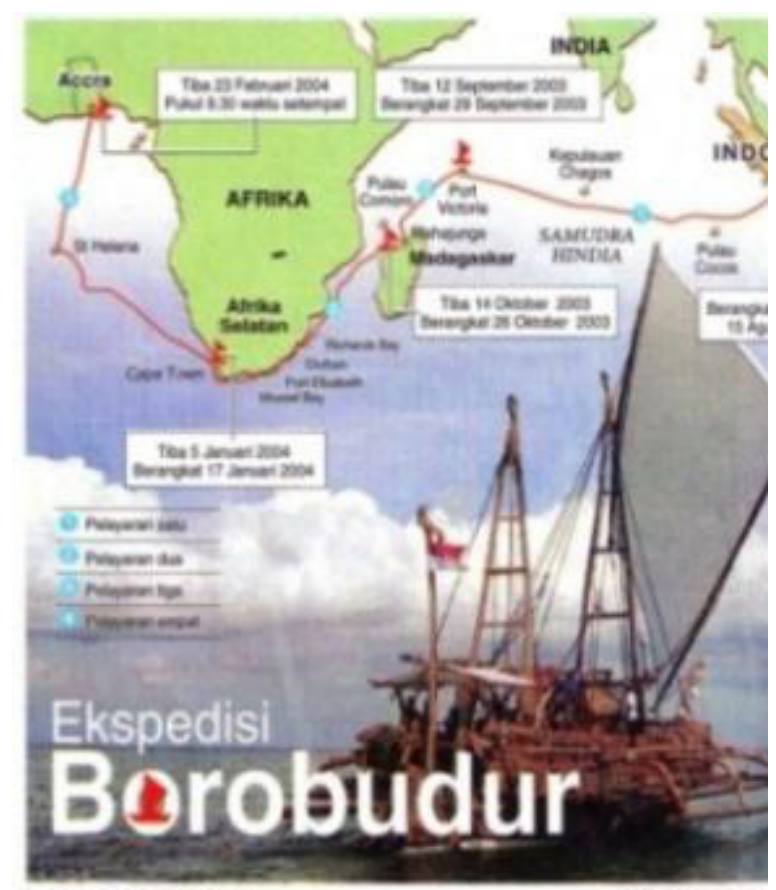

Gambar 19. Rute replika

Cadik Samudra Borobudur

diujung selatan benua Afrika yang terkenal ganas ombak lautnya. Replika dibuat semirip mungkin dengan cadik samudera pada relief candi Borobudur. Digunakan teknologi maritim dan bahan-bahan semendekati aslinya. Ukurannya panjang $18.29 \mathrm{~m}$, lebar $4.25 \mathrm{~m}$ (dari lunas - geladak), dan berat 30 gros ton. Setelah menempuh perjalanan sejauh $20.372 \mathrm{~km}$, replika tiba di pelabuhan Tema di Acra, ibu kota Ghana di pantai barat benua Afrika ditepi samudera Atlantik pada tanggal 23.2.2004. Replika kemudian dibongkar dan diangkut ke Indonesia dan dirakit kembali, lalu ditempatkan di sebuah anjungan di kompleks candi Borobudur.

Sementara itu para pencari rempah rempah Eropa masih menggunakan Khyber Pass - jalan Sutera di benua Asia. Armada Eropa baru berani menyusur pantai dan belum berani menyeberangi samudera. 1292 Marco Polo baru berani menyeberangi samudera dari Mala- ya ke Goa di India. 1492 Columbus baru berani menyeberangi samudera Atlantik ke benua Amerika. Pelaut Eropa yang berani melewati Tanjung Harapan yang ganas baru terjadi 700 tahun setelah para pelaut pedagang Nusantara melalui Tanjung Harapan dan sampai di Acra. 1487 Bartolomeo Diaz, 1497 Vasco de Gama, dengan kapal samudera yang lebih besar.

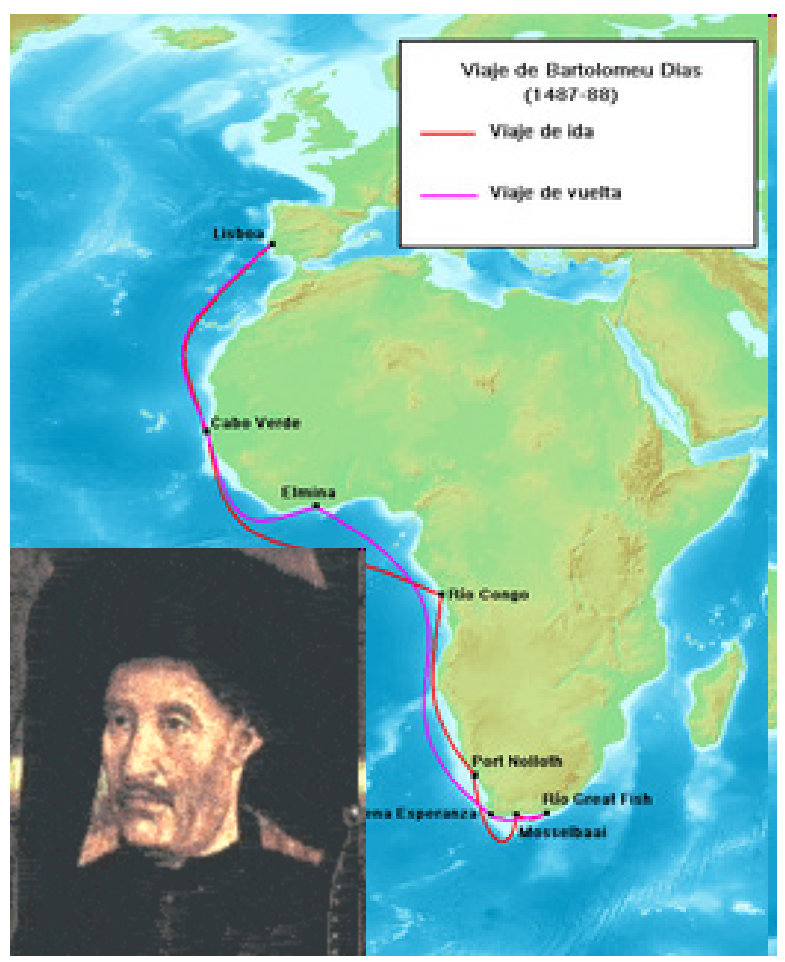

Gambar 20.

Pelayaran BARTOLOMEO Diaz

\section{INFO MENDEBARKAN 11: Arus balik, katastrofi Purba, Mitigasi bencana}

Mungkinkah manusia dari Asia yang oleh teori benua-darat (barat) diklaim masuk ke Nusantara 5000 SM dan 2000 SM dan disebut sebagai cikal bakal manusia Nusantara itu merupakan "arus balik", mudiknya keturunan para pengungsi Nusantara saat ledakan dahsyat gunung Toba Purba dan banjir banjir besar dulu?

Setelah ribuan tahun dirantau orang menunggu meredanya katastrofi purba yang berulang ulang terjadi, sampai keadaan pulih dan stabil kembali?. Ini bisa menjelaskan banyak hal. Misalnya mengapa yang 'dibawa' manusia yang 
datang dari Asia 5000 SM dan 2000 SM tsb mudah diterima di Nusantara. Ini karena yang dibawa masuk merupakan 'pusaka' warisan nenek moyang kita sendiri, yang kembali ke haribaan ibu Pertiwi!. Penjajah Belanda memperlakukan kepulauan Nusantara sebagai bagian dari benua-darat, pembangunnya berat kedarat. Tentunya ini disengaja penjajah yang "mengklasifikasikan" Nusantara sebagai agraris dengan cultuurstelsel sebagai senjatanya. Penjajah Belanda tahu betul bahwa kekuatan Nusantara dulu adalah dilaut, oleh sebab itu mereka berusaha keras agar putra putri Nusantara lupa jiwa baharinya, bahkan dongeng pahlawan pelaut pedagang kita yang mencapai Madagaskar sebelum Masehi, sejauh $6500 \mathrm{~km}$ dan Acra di Ghana pantai barat Afrika ditahun $800 \mathrm{M}$, sejauh $20.371 \mathrm{~km}$, menghilang entah kemana.

Kita lebih kenal dengan VASCO DE GAMA dan BARTOlomeo Diaz serta tokoh dongeng pelaut Barat seperti Thor, Norman, Erick, dan sebagainya, yang dengan gigih dipropagandakan penjajah melalui jalur sekolah. Celakanya ketika kita merdeka, kita ikut ikutan membangun $\mathrm{Nu}-$ santara dengan juga berat kedarat, tidak heran bila setelah hampir 70 tahun merdeka, pembangunan Indonesia sulit untuk bisa seimbang, selaras, serasi dan lestari. Bumi-maritim, tanahair, mencakup laut dan pulau, jadi pembangunan tidak boleh mengabaikan salah satu, dan dengan laut sebagai pemersatu.

\section{INFO MENDEBARKAN 12: \\ Nusantara: Muncul \& Perkembangannya}

Demikianlah suatu waktu setelah laut turun dan stabil, munculah untaian pulau besar dan kecil membentuk kepulauan Nusantara. Jadi wawasan Nusantara dulu, barulah muncul pulau, daerah, lokasi, suku. Sejak itu manusia kepulauan Nusantara mulai menetap. Penduduk memilih pulau, daerah atau lokasi dengan lingkungan yang berbeda. Tidak heran bila tiap pulau, daerah, lokasi memiliki kemampuan untuk memadukan sesuatu yang datang dari luar dengan apa yang telah dimiliki hingga berkembanglah kebu- dayaan tanpa kehilangan jati diri.

Terjadilah proses interpelasi tanpa henti hingga menghasilkaan keunikan tiap pulau/ daerah/ lokasi/suku yang tidak statis, tapi cepat atau lambat terus berkembang dengan masuknya unsur baru dari luar. Bersamaan dengan itu rasa kekeluargaan sebagai anak cucu dari nenek moyang yang sama, persaudaraan manusia kepulauan sebagai manusia bahari benua Maritim, memunculkan wawasan Nusantara yang bercorak Bhinneka Tunggal Ika.

Jadi wawasan Nusantara dan Bhinneka Tunggal Ika sebenarnya setua prasejarah, walaupun lambang Bhinneka Tunggal Ika baru diresmikan setelah Proklamasi kemerdekaan kita, dan wawasan Nusantara baru dideklarasikan oleh kabinet Djuanda (15.12.1957) dan kemudian diakui dunia melalui Konvensi Hukum Laut PBB (1982).

\section{INFO MENDEBARKAN 13: Dualisme Dwitunggal}

Dalam tradisi Nusantara tidak ada karya kriya (seni rupa \& desain) yang dibuat semata untuk keindahan, sebaliknya tak ada benda pakai yang asal bisa dipakai, ia pasti indah. Indahnya bukan sekedar memuaskan mata, tapi melebur dengan kaidah moral, adat, tabu, agama, dan sebagainya, hingga selain bermakna, sekaligus indah.

Dalam perupaan seni tradisi di Indonesia, tidak ada yang senaturalis atau seabstrak Barat, yang disukai dekoratip dan ragam hias. Juga tak ada yang se simetri atau se asimetri Barat, yang disukai keseimbangan dinamis, juga tak disukai berpikir dan berkomunikasi yang se konkrit atau se abstak Barat, yang disukai simbolik.

Semuanya ini erat hubungannya dengan tradisi Nusantara yang bersifat "Dualisme Dwitunggal" (mono dualism). Ada dunia atas: Dewa, angkasa, gunung, lelaki, baik, kanan, dan sebagainya. Sebagai pasangannya ada dunia bawah: manusia, laut, wanita, jahat, kiri, dan sebagainya. Dualisme ini bukannya untuk diper- 
tentangkan, tapi untuk diintegrasikan. Untuk itu dilibatkan dunia tengah (antara): mahluk melata dan ampibi, serta pohon hayat yang berakar di dunia bawah dan menjulang menggapai langit. Yang penting bukan mana yang lebih unggul, kuat, berkuasa, tapi bahwa keduanya perlu bekerja sama dan yang satu belum lengkap bila belum didampingi pasangannya. Kemajuan difahami sebagai hasil integrasi dari dualisme ini menjadi dwitunggal atau tritunggal (dengan dunia tengah). Di Indonesia secara tradisional dualisme diintegrasikan jadi dwitunggal atau tritunggal: agar seimbang, selaras, serasi dan lestari. Demikianlah kawasan kepulauan memunculkan ciri yang unik dalam kebudayaannya: Dualisme yang dwitunggal atau tritunggal, yang jadi pemersatu kawasan benua Maritim yang berwawasan Nusantara dan bercorak Bhinneka Tunggal Ika.

Ini berbeda dengan Barat yang memahami kemajuan sebagai hasil pertentangan antara dualisme (dua kutub yang bertentangan: kiri vs kanan, pria vs wanita, baik vs jahat, dan sebagainya), dikenal sebagai dialektika. Kemajuan dihahami sebagai hasil konflik kedua kutub dualisme tersebut, jadi harus ada korban. Ini sesuai dengan epistemologi pemikiran Barat yang membangun semacam dua kebudayaan yang eksklusip (Teori 'Two Culture'), teori 'The Great Devide', yang menghasilkan 'Oposisi Biner': memihak satu dunia dan meminggirkan dunia yang lain. Menciptakan dunia sebagai kompartemen-kompartemen yang statis, kaku dan njaris absolut (lihat Yasraf Amir Piliang, dalam PriMADI, TABRANI: 2006: xix)

\section{INFO MENDEBARKAN 14: \\ Nusantara Purba, Laut Pemersatu, Wawasan Nusantara.}

Ada berbagai legenda yang bercerita bahwa penduduk kawasan pantai selatan Kalimantan, pantai timur Sumatera, dan pantai utara Jawa, kesemuanya sama-sama menyebut dirinya "anak air" bukan anak laut (Laut Jawa). Ternyata dimasa Paparan Sunda dan Paparan Sahul masih

menggejala, di masa osilasi Jaman Es terakhir, ketika manusia sudah mulai bermukim di kawasan Nusantara Barat, diantara tiga pulau itu mengalir beberapa sungai purba raksasa yang bermuara di laut Cina Selatan dan di sebelah timur laut Jawa, dengan berbagai anak sungai yang berasal dari Kalimantan, Sumatera dan Jawa (lihat gambar). Bukti adanya sungai-sungai purba ini antaranya berkat bantuan teknologi modern Inderaja (remote sensing).

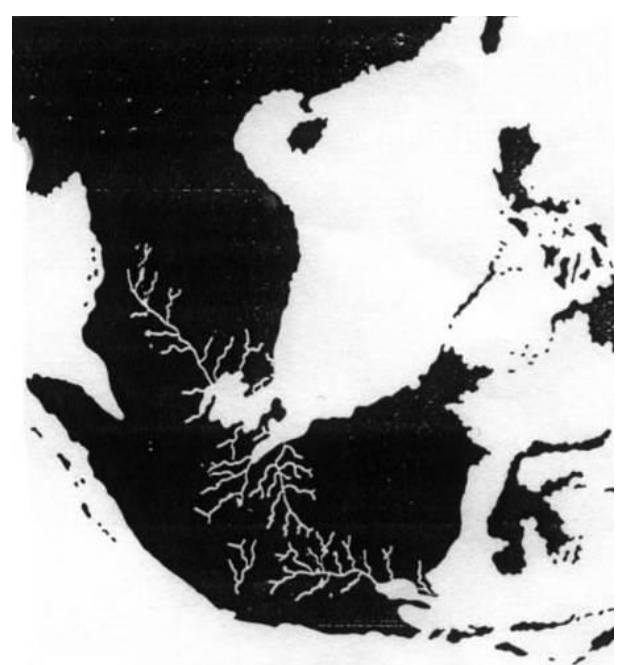

Gambar 21

Sungai purba didangkalan Sunda.

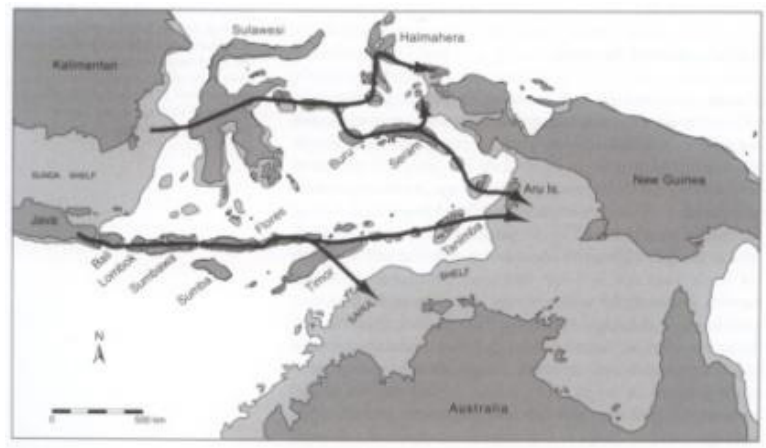

Gambar 22. Laut pemersatu.

Bukti lain bisa dilihat di Anjungan Ikan Air Tawar di Taman Mini Indonesia Indah. Disana diperagakan kesamaan ikan-ikan di sungai sungai di selatan Kalimantan, di utara Jawa, di Timur Sumatra, kesemuanya bermuara di sungai raksasa purba yang kini menjadi laut Jawa. Permulaan peradaban dimulai dikedua tepian sungai raksasa, begitu pula di Nusantara. Aliran rangkaian sungai purba raksasa didangkalan Sunda tsb berawa rawa, oleh sebab itu hunian 
di masa itu adalah gua, bukit dan gunung serta dataran tinggi ditepian wilayah rawa rawa tsb. Bukankah lingkungan ini merupakan 'wadah' ideal bagi lahirnya budaya perahu? Mengapa teori benua-darat (barat) menyebut perahu berasal dari Hunan di pedalaman Cina? Berbagai pemukiman ditepian aliran sungai berawa rawa yang terkadang melebar dan menyempit di masa osilasi Jaman Es dengan permukaan laut yang naik dan turun, meninggalkan kenangan kuat bahwa anak air diseberang sana - yang kemudian dipisahkan oleh laut Jawa - jadi pulau: Sumatera, Kalimantan, Jawa, adalah saudara-saudara kita juga. Hubungan kekeluargaan kaum "anak air" di Paparan Sunda di tepian daerah aliran sungai-sungai purba tsb itu memang sudah ada sejak prasejarah. Laut sebagai pemersatu terjadi pula antara Sumatera-Kalimantan-Jawa. Masih di prasejarah nenek moyang kita telah meretas rute laut pulang pergi dari Jawa dan Kalimantan, melalui pulau-pulau di timurnya sampai Papua dan tiba di Australi sekitar 60.000 SM. Jadi untuk Nusantara laut adalah pemersatu bukan pemisah.

\section{Nusantara Indonesia}

Jadi, tidak usah heran bila dalam sejarah Indonesia seakan ada benang merah yang menghubungkan wangsa-wangsa raja-raja di Kalimantan (sejak Kutei) dengan raja-raja di Sumatera, Jawa, Sulawesi, Ternate. Tidore, Bali, Nusa Tenggara Barat, Nusatenggara Timur, Maluku, Papua. Setelah kepulauan Indonesia memperolah bentuknya seperti yang kita kenal sekarang, maka "komunikasi" (laut) antara Sumatera, Kalimantan dan Jawa sampai ke Papua tetap merupakan bagian dari kehidupan sehari hari, komunikasi antara kaum anak air yang dipersatukan oleh laut. Sejarah mencatat bahwa komunikasi laut dengan benua Australi tidak pernah terputus, penangkapan ikan dan teripang membawa nelayan kita sampai ke benua Australi.

Mereka istirahat sejenak di pemukiman sementara di Arnhem Land Australi yang merupakan tepian laut Nusantara, memasak teripangnya dan baru kemudian pulang. Di Arnhem
Land banyak dijumpai garca perahu nelayan Nusantara. Hal ini baru jadi masalah di akhir abad XX dengan adanya perjanjian perbatasan antara Republik Indonesia dengan Australi.

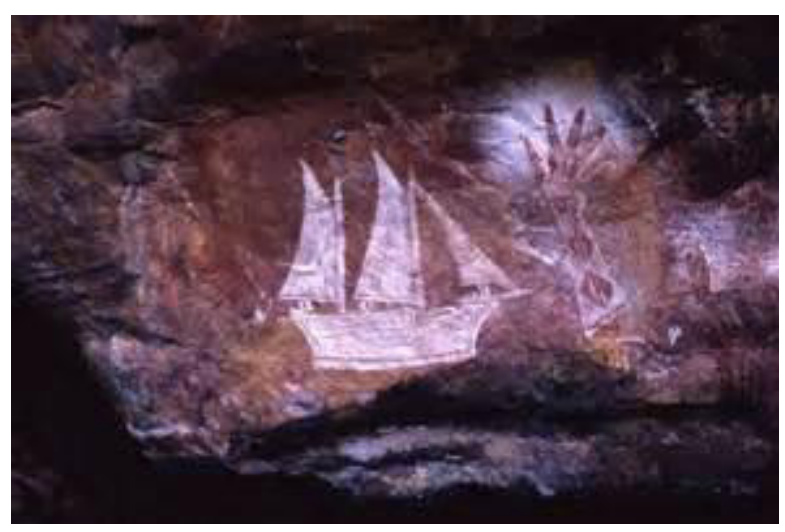

Gambar 23.

Garca di Arnhem Land

\section{INFO MENDEBARKAN 15: Bhinneka Tunggal Ika}

Kawah Candra Dimuka tempat menggembleng manusia dengan tradisi benua-darat yang memasuki paparan Sunda dan Sahul adalah perubahan Paparan Sunda dan Sahul menjadi kepulauan Nusantara, yang memakan waktu puluhan ribu tahun pada Jaman Es Quartair, hingga bermetamorphosa jadi manusia benua maritim yang berjiwa bahari.

Tiap suku/daerah/pulau mampu memadukan apa yang datang dari luar dengan apa yang telah dimiliki, hingga berkembanglah kebudayaan tanpa kehilangan jati diri, dan sekaligus semuanya merupakan bagian dari satu benua-maritim yang berwawasan kebudayaan Nusantara: Bhinneka Tunggal Ika dengan dualisme dwitunggalnya. Budha di Palembang berbeda dengan yang di Jawa Tengah; Hindunya Kutei di Kalimantan berbeda dengan yang di Jawa Tengah dan Bali. Islamnya Minang berbeda dengan yang di Sunda, Jawa atau Makasar. Perhelatan Mauludan di Cirebon disebut 'Panjang Jimat' dan perhelatan Mauludan di Jogya yang disebut 'Sekaten'.

Semua yang datang dari luar pasti diolah hingga tinggi muatan lokalnya, bahkan juga 
muatan kebangsaannya. Jadi motto Bhinneka Tunggal Ika bukanlah sekedar keputusan politis setelah proklamasi kemerdekaan, tapi sudah begitu dari "sono"nya.

\section{Semangat Kebangsaan}

Tak sedikit raja Jawa dan Sumatera yang setelah meninggal diperingati sekaligus dengan dua candi berlainan agama, bahkan ada yang diperingati dengan satu patung mencitrakan dia sebagai Siwa-Budha. Ada masa Hindu berkuasa di kawasan utara Jawa Tengah dan Budha di kawasan selatan. Namun di masa itu sejumlah candi Budha didirikan di tanah yang dihibahkan oleh raja Hindu dan sebaliknya!! Hindu dan Budha yang saat masih di benua-darat sering berselisih , ternyata di Indonesia berada dalam satu candi di Plaosan Jawa Tengah.

Dakwah agama Islam di Jawa tanpa canggung memanfaatkan wayang kulit yang Hindu. Begitu pula dakwah agama Kristen. Dalam wayang setelah Islam masuk ke Indonesia, tokoh wayang, agama, dewa, raja, roh nenek moyang direkayasa menjadi satu cerita.

Majapahit yang Hindu, tetapi pemujaan roh nenek moyang, agama Budha dan agama Islam diperkenankan hidup berdampingan. Di Trowulan, ibu kota Majapahit ditemukan makam Islam Troloyo, sementara gunung Penanggungan merupakan semacam pusat nyepi berbagai macam aliran kepercayaan dan pemujaan roh nenek moyang. Jadi, manusia di kawasan Nusantara ini tidak mau dipecah-belah oleh sesuatu yang datang dari luar, agama sekalipun. Penduduk kawasan ini lebih cinta Indonesia daripada harus berperang karena sesuatu yang datang dari "luar". Semangat kebangsaan ini sudah begitu sejak semula dan pengikatnya adalah benua-maritim yang berwawasan Nusantara dengan dualisme dwitunggal dan Bhinneka Tunggal Ikanya. Hal ini sunguh berbeda dengan apa yang terjadi pada manusia "Benua-darat", yang bukan hanya antara agama yang berbeda, tapi pula tiap aliran agama, cenderung jadi "fundamentalis" yang menganggap dirinyalah yang paling benar, dan siap berperang dengan agama/aliran agama yang lain dalam suatu perang yang tiada akhir.

\section{Sumpah Pemuda}

Bagaimana kuatnya semangat kebangsaan ini diatas kepentingan suku/daerah/ pulau/ agama/ aliran, tampak pada Sumpah Pemuda 1928 dimana berbagai gerakan pemuda yang bersifat kesukuan/ daerah/ pulau/ agama/ aliran kepercayaan, bukan hanya memantapkan kawasan Nusantara menjadi satu tanah air, penduduk yang hidup di kawasan ini satu bangsa: Indonesia, tapi pula satu bahasa persatuan, bahasa Indonesia. Bahasa Indonesia semula belum ada! Betul betul diciptakan!. Tanpa perang, tanpa ribut-ribut, cukup dengan ikrar dalam sebuah Kongres Pemuda berusia 20 tahunan di tahun 1928.

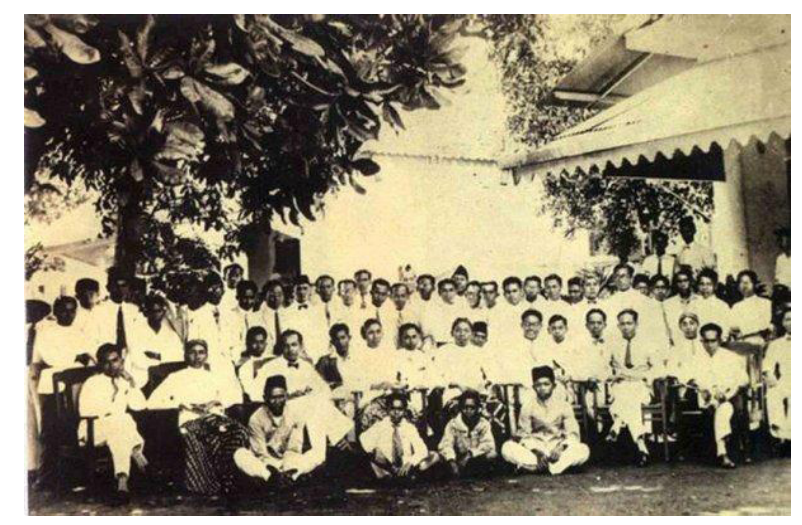

Gambar 24.

Konggres Pemuda II.

Bila digunakan demokrasi benua-darat (barat) dengan jumlah pendukung suatu bahasa, jelas bahasa Jawa yang terbesar pemakainya akan menang. Bukan pula nama bahasa Melayu, yang sungguhpun kalah banyak pemakainya dengan bahasa Jawa, tapi sudah menjadi lingua franca - bahasa perantara di kota kota pantai Sumatera, Jawa dan Kalimantan. Yang menang justru semangat kebangsaan: satu tanah air/bangsa/ bahasa: Indonesia. Jadi, negara kesatuan Indonesia, satu tanah air/bangsa/bahasa, benua maritim dengan wawasan Nusantaranya bukanlah hasil suatu perang penaklukan (seperti teori 
yang terjadi di ilmu "benua-darat"). Ia sudah demikian sejak semula, kawasan ini adalah ibu pertiwi yang kemudian melahirkan Indonesia.

Tiap daerah/pulau/suku memadukan apa yang datang dari luar dengan apa yang telah dimiliki hingga berkembanglah kebudayaan tanpa kehilangan jati diri. Kita menghormati tradisi, hingga bisa jadi penyaring ("filter") bagi apa yang datang dari luar. Sejak semula kawasan ini berhasil menjinakkan "Globalisasi" dengan prinsip Bhinneka Tunggal Ika dan Dualisme Dwi Tunggal.

Perkembangan budaya merupakan kesinambungan, pengulangan dengan perubahan, 'sangkan paraning dumadi'. Kesinambungannya bahkan dapat dirunut sampai ke prasejarah. Budaya Prasejarah sangat kuat pengaruhnya karena ia merupakan jaman yang terlama dalam sejarah Indonesia, puluhan ribu tahun lamanya. Jadi proses perkembangan kebudayaan di Indonesia: di hari ini dengan belajar dari masa lalu kita mendesain untuk masa depan. Suatu proses interpelasi yang tiada henti, jadi sesungguhnya sejak semula budaya Indonesia sudah "Post Modern".

Jadi Wawasan Nusantara dulu, kesatuan dulu, baru ada pulau, daerah, suku. Hal ini sungguh berbeda dengan "teori Benua-darat" yang mulai dengan suku-suku dulu, yang dipersatukan oleh persamaan nasib hingga terbentuklah bangsa.

\section{INFO MENDEBARKAN 16: Jatidiri Indonesia}

Pelaut kawasan kepulauan yang singgah di suatu pulau, karena cuaca yang tidak selalu dapat diduga, bisa tertahan sehari, seminggu atau lebih. Maka lebih baik damai dengan penduduk setempat daripada memusuhinya. Begitu pula penduduk suatu pulau di kawasan kepulauan lebih baik damai dengan pendatang, sebab mereka satu waktu bisa pula terdampar di pulau lain.

Jadi manusia kepulauan mirip dengan kaum Gipsi Eropa yang suka damai, sebagai kekec- ualian pada manusia benua-darat, yang agresip - defensip.

Jelas bahwa manusia Indonesia adalah manusia kepulauan di Benua Maritim, yang sejak semula berjiwa bahari, berani berpetualang, berani ambil risiko, suka mengembara sampai ke ujung dunia yang tidak nampak, sekaligus bersifat integratip, plural, kekeluargaan dan cinta damai.

\section{Kota kota yang tebuka}

Bila kota berpagar tembok benteng merupakan sesuatu yang biasa bagi kota di benua-darat, maka kota asli Indonesia, misalnya Trowulan, ibu kota Majapahit sebagai salah satu kerajaan terbesar di Nusantara, di puncak masa kejayaannya, tidak memiliki pagar tembok kota berbenteng. Trowulan kota di pedalaman, merupakan kota air dengan berbagai kanal (lebar sekitar 25 $\mathrm{m}$, terpanjang sekitar $6,25 \mathrm{~km}$ ) yang berpotongan tegaklurus, serta punya akses ke laut melalui sungai gunting dan sungai Brantas (lihat gambar). Misteri ini baru tersingkap berkat penelitian lintas sektoral antara arkeologi dengan teknologi penginderaan jauh. Kota bertembok benteng, baru dikenal di Indonesia setelah masuknya Islam dan bangsa Eropa ke Indonesia, seperti Banten, Makasar, Jogya, Solo dan sebagainya.

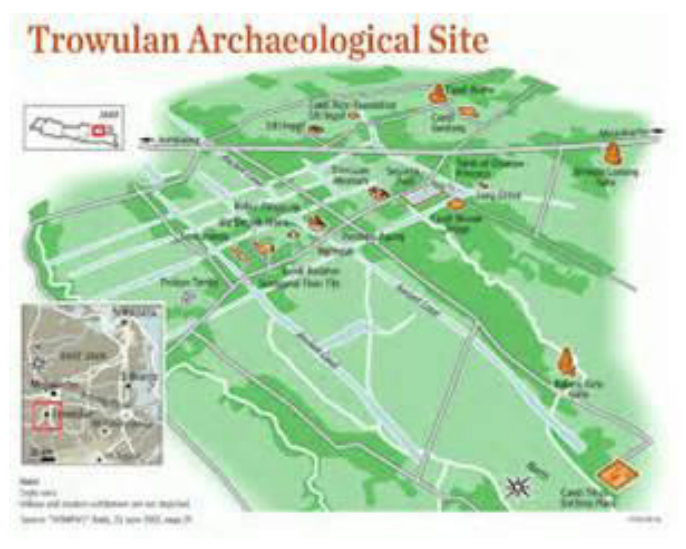

Gambar 25. Trowulan. 


\section{KESIMPULAN}

Belajar dari sejarah \& perkembangan Lingkungan. Sepanjang Sejarah dan perkembangan Lingkungan Nusantara sejak jaman purba, aneka info-info yang mendebarkan telah banyak terjadi dan umumnya diteliti peneliti asing.

Tulisan ini telah menunjukkan bahwa hasil penelitian para pakar asing itu terkadang bias, 'pro penjajah'. Penjajah di gambarkan unggul, maju, pandai, kuat, kaya, dibanding dengan negara yang 'dijajah'nya. Tentu banyak pula peneliti yang 'jujur'. Seperti Robert Dick ReAd dengan Penjelajah Bahari, Pengaruh Peradaban Nusantara di Afrika, dan Stephen Openheimer dengan Eden in the East.

Di Gunung Padang, peneliti asing tak terlibat, hanya sebagai undangan, atau bahkan 'turis'. Tapi hasil penelitian mereka fenomenal, karena mereka memanfaatkan info-info mendebarkan yang telah diteliti dimasa lalu. Silahkan buka Google atau Yahoo, dsb, maka bisa diproleh banyak rekonstruksi imajiner Gunung Padang. Adalah keyakinan penulis bahwa masalah pertumbuhan dan perkembangan kebudayaan tak mungkin dipecahkan sendirian oleh satu disiplin ilmu. Tapi perlu 'dikeroyok' oleh banyak disiplin ilmu. Masing masing ilmu perlu 'melonggarkan' batasan-batasan masing-masing untuk memungkinkan beragam ilmu tsb bekerja sama secara integratip.

Telah disebut bahwa kita sudah perlu meninggalkan epistomologi dalam pemikiran Barat yang membangun semacam dua kebudayaan yang eksklusip - Teori 'Two Culture", dan teori 'The Great Devide', yang menghasilkan 'Oposisi Biner': memihak satu dunia dan meminggirkan dunia yang lain. Menciptakan dunia sebagai kompartemen-kompartemen yang statis, kaku dan njaris absolut (YASRAF AMIR Piliang, dalam Primadi TABrani: 2006: xix). Perkembangan sejarah dan lingkungan sejak jaman purba bukanlah titik-titik yang behenti. BERGSON menyebut perkembangan itu sebagai duree, EINSTEIN menyebutnya sebagai continuum, Fritjof KAPRA menyebutnya sebagai pros- es. Tak ada yang abadi, semua berubah - yang abadi adalah perubahan itu sendiri.

Bukankah dalam sejarah ini sering terjadi?! Dulu ada teori bahwa bumi merupakan pusat jagad dan matahari mengelilingi bumi. Ketika Copernicus dengan perhitungan matematik menemukan bahwa mataharilah pusat dan bumi yang mengelilinginya, pendapat ini di 'cuekin', ketika berpuluh tahun kemudian GALILEO dengan telescop menemukan fakta bahwa COPERNICus benar, ia nyaris dihukum mati. Untung akhirnya GALILEI dibuang ke kota kecil, tapi tidak boleh mengajarkan bahwa matahari pusat dan bumi mengelilinginya.

Semula ada teori bahwa dunia itu datar, bila sampai ke ujungnya akan jatuh keluar dan tak bisa kembali. Itu sebabnya ketika Columbus mencari rempah-rempah tidak ke timur, tapi ke barat, maka dari tiga kapal yang berangkat, dua memutar haluan dan kembali ke Eropa, mereka takut jatuh keluar!. Hanya Kapal Columbus yang meneruskan pelayarannya dan mencapai West Indies, untuk membedakannya dengan East Indies (Indonesia).

Garca prasejarah pertama ditemukan di Altamira, Eropa. Para ilmuwan pada masa itu, terutama para arkeolog, yakin bahwa penemuan itu merupakan penipuan. Menurut mereka manusia prasejarah masih liar, biadab, kasar, tidak kreatip dan mana mungkin punya ketrampilan melukis yang tak kalah indahnya dengan seniman masa kini. Sampai kinipun masih banyak kaum sekolahan kita yang berpendapat seperti itu.Bukankah danau Bandung purba 'seketika' berubah dahsyat. Masa lalunya tersisa sebagai legenda, dongeng, titik-titik yang 'abadi'. Namun setelah 'seketika' tsb perkembangan cekungan Bandung terseret dimensi waktu dan ruang yang berbeda.

Seperti kata 'nenek': "Bila dikehendakiNya, yang terjadi, terjadilah", dan kita, manusia, homosapiens merupakan bagian dari kejadian tsb, yang menjangkau dimensi waktu sejak masa lalu, masa sekarang, masa depan, dan kini bukan hanya di bumi, tapi merambah alam semesta. 


\section{DAFTAR PUSTAKA}

BAKOSURTANAL.

1992 Video Inderaja dan Arkeologi - Kasus Trowulan

Belwood, Peter.

2000 (1985, 1997), Prasejarab Kepulauan Indonesia - Malaysia. Edisi revisi, PT Gramedia Pustaka Utama, Jakarta.

Chaloupka, George.

1993 Journey In Time, Reed Books Of Australia, Virginia, Australia

ECONOMICA.

1992 Menggugat Budaya Jawa, Mimbar Ekonomi, Sosial Dan Budaya, Universitas Indone sia, Jakarta.

ENCYCLOPEDIA BRITANNICA.

jilid XI: 268/272/277, XIII:444/469, XXI:168/172, XXII:722, 754-64, XXV: 257-58/270/273, XXVIII: 758, Encyclopedia Britannica Inc., Chicago.

Garis Depan Nusantara.

2007 Peringatan 50 Tabun Deklarasi Djuanda.

GrAAF, H.J.DE.

1987 Akbir Masa Majapahit, seri terjemaha Javanologi, Jilid I, Grafiti Press, Jakarta.

HARIMURTI KRIDALAKSANA.

2009 Masa Masa Awal Bahasa Indonesia, Lab oratorium Leksikologi dan Leksikogra fi, Fakul tas Ilmu Pengetahuan Budaya, Universitas Indonesia, Depok.

HEEKEREN, HR VAN.

1972 The Stone Age Of Indonesia, Koniklijke Instituut voor Taal, Land en Volkenkunde, The Hague.

KING, M, Elizabeth.

- Possible Indonesian Or South East Asian Influence In New World Textile Industries, The University Museum, University of Pensilvaniya, Philadelphia, Pen silvaniya, USA.

KROM, N.J.

1927 Barabudur-Archeological Description, Mar tinus Nijhoff, The Hague.

LEWCock, Ronald \& Gerard Brans.

1980 The Boat as an Architecture Symbol, dalam OLIVER, Paul, 1980, SHELTER, SIGN, SYMBOL, The Overlook Press, New York:107116.

Luc Henry Fage, Jean Michel Chazinne, PINDI SETIAWAN.

Borneo, Menyingkap Gua Prasejarah, Le Kalimanthrope, Indonesia \& Le Jonty, F82160 Caylus, Perancis.

Meulen, SJ. VAn Der.

1988 Indonesia Diambang Sejarah, Penerbit Kanisius, Yogya.

Morwood, MiKe.

2002 Vision from the Past, Smithsonian Insti tution Press.

ONGHOKHAM.

1962 Penelitian Kebudayaan Jawa, Economica, 1962, NO 26, Universitas Indonesia.

OPENHEIMER, STEPHEN.

1999 Eden In The East, George Wiedenfield \& Nicholson, Ltd, England.

Piliang, YASRAF AMIR

2008 Multiplisitas Dan Differensi, Jalasutra, Yogyakarta.

Poniman, Aris.

1981 Penerapan Teknik Penginderaan Jauh untuk Inventarisasi dan Penelitian Pen inggalan-peninggalan daerah Trowulan, Bakosurtanal, Cibinong.

PRIMADI TABRANI.

2011. Belajar Dari Sejarah Dan Lingkungan, Penerbit ITB , Bandung.

2003 Indonesian Visual Art, a never ending pro cess of interpelation, katalog $C P$ OPEN BIENNALE 2003, Jakarta: 36-40.

205, 2010, 2012, Bahasa Rupa, Penerbit Kelir, Kabupaten Bandung. 
2006, 2012, 2014, Kreativitas \& Humanitas,

Sebuah Studi Tentang Peranan

Kreativitas Dalam Perikehidupan Manusia,

Penerbit Jalasutra, Yogyakarta.

READ, ROBERT DiCK.

2008. Penjelajah Bahari, Pengarub

Peradaban Nusantara Di Afrika,

Penerbit Mizan, Ujung Berung,

Bandung.

RETNO BINTARTI.

2004 Sebelum Lewat Tanjung Harapan Hati Masih Ciut. Kompas.

SANTOS, ARYSIO.

2010 cetakan kedua, Atlantis, The Lost Conti nent Finally Found, Library of Congress, Washington.

SETIAWAN, Pindi.

1994 Gambar Cadas Dunwahan - Tinjauan

Awal Analisa Isi Wimba Berdasar

Posisi Sebenarnya Di Cadas. Skripsi Sarja

na Seni, Fakultas Senirupa dan Desain ITB.

SOEDJOKO.

1981 Ancient Indonesian Technology, Shipbuilding And Arms Production Around The Xvi Cen tury, Dalam Aspects Of Indonesian Archeol ogy, Pusat Penelitian Arkeologi Nasion al, Jakarta.

\section{PUSTAKA GAMBAR}

1. Tembok Besar Cina, http://.bing.cpm/ im ages/search?q=tembok+besar+cina. Diunduh 6.7.2014

2. Paparan Sunda dan Sahul, diolah dari Morwood 2002: 3

3. Ledakan Toba Purba. http://indocrpcircles.worldpres.com/2012/01/06/stephen-openheimer.Diunduh 2.7.2014

4. Migrasi Baru. http://indocrpcircles.worldpres.com/2012/01/06/stephen-openheimer.Diunduh 2.7.2014.
5. Paparan Sunda. Heekeren, 1972.

6. Rekonstruksi imajiner punden berundak Gunung Padang, http://bing/com/ search?q=gunung + padang +2014 . Diunduh 19.8.2014.

7. Rekonstruksi imajiner seluruh kompleks Punden berundak Gun ung Padang. http://bing/com/search?q=gunung+padang+2014. Diunduh 19.8.2014.

8. Punden Berundak candi Borobudur. http://bing.com/images/search?q= indonsian+ pyramids. Diunduh 19.8.2014.

9. Punden berundak candi Sukuh. http:// bing $/$ com $/$ search?q=indonesian+ pyramids. Diunduh 19.8.2014.

10. Punden Berundak Prasejarah di Banten. http://bing.com/images/search?q= punden + berundak + banten. Diunduh 19.8.2014.

11. Punden Berundak - piramid Mesir. http:// bing/com/search?q=egypt+pyramid. Diunduh 19.8.2014

12. Punden berundak Mesopotamia. http:// bing $/ \mathrm{com} /$ search?q=Mesopotamia + Temples+ziggurat. Diunduh 19.8.2014

13. Punden Berundak Aztec di Mexico. http://=aztec+pyramid. Diunduh 19.8.2014.

14. Garca P. Kei Kecil, diolah dari Pindi Setiawan, 1994: 81

15. Cadik Prasejarah, http://www.migrationheritage.nsw.gov.icms/wp.content/ uploads/2012/02/indonesia-outrigger.jpg. Diunduh 2.7.2014

16. Sundaland. http://bing.com/images/ searcg?q $=$ asia + tenggara + pacific. Diunduh 6.7.2014

17. Rumpun Bahasa Austronesia. http://.bing. $\mathrm{com} /$ images $/$ search?q=asia + tenggara + pacific. Didunduh 6.7.2014 
18. Cadik Samudera Borbudur. Koleksi pribadi

19. Rute replika Cadik Samudera Borobudur, Retno Bintarti, Kompas 8.3.2004:48

20. Pelayaran Bartolomeo Diaz. http://.mediatheek.thinkquest.int/-11069/dutch/index. php3=voyages/asia/portugal; Diunduh 20.12 .

21. Sungai Purba, Peter Belwood, 2000 (1985. 1997): 44

22. Laut Pemersatu, Mike Morwood, 2002: 8.

23. Garca di Arnhem Land, jpek, independent. co.uk, diunduh 23.6.2014

24. Konggres Pemuda II - 1928, id.wikipedia. org, diunduh 24.t.2014

25. Trowulan, gif.numbingeveryday.blgspot. com. diunduh 23.6.2014 